\title{
Validity Teaching Materials of Indonesian Education In Beginning Class of Elementary School Course Based Integrated Science and Social Studies
}

\author{
Wahyu Sukartiningsih ${ }^{1)}$ \\ ${ }^{1)}$ UNESA, Semarang, Indonesia \\ E-mail:wahyujk.unesa@yahoo.co.id
}

\begin{abstract}
The aim of the research is to develop teaching materials of Indonesian education in beginning class of elementary school course based integrated science and social studies based Scientific Approach to optimize students competence in Elementary School Teacher Education Department. The specific objective of the first study to explain the validity of teaching materials of Indonesian education in beginning class of elementary school course based integrated science and social studies based Scientific Approach to optimize students competence in Elementary School Teacher Education Department. This study consists of two main steps: Firstly, to design teaching materials refers to the 4-D model of development; Secondly, to explain validity the teaching materials. Data collection techniques is questionaire. The research instrument consisted of Questionaire respon. Data from this study were analyzed by descriptive statistics, such as score of quesionaire Response students and lecturer. The results showed that the teaching materials of Indonesian education in beginning class of elementary school course based integrated science and social studies based Scientific Approach to optimize students competence in Elementary School Teacher Education Department was valid.
\end{abstract}

Keywords: Teaching Materials, Indonesian Education in Beginning Class of Elementary School Course, Science and Social Studies, Scientific Approach, Students Competence in Elementary School Teacher Education Department

\section{INTRODUCTION}

Curriculum 2013 is a curriculum designed to enhance previous curriculums. The curriculum is based on 2013 levels Elementary School (SD) using the integrated thematic learning with a view to providing the ability and experience of a holistic and comprehensive in students. In this case, learning is no longer presented in the form of a segmented every subject, but presented in a thematic integrated. Integrated thematic learning is a merger of two integrated learning model that is webbed and integrated. Fogarty (1991: 54) says "webbed curricula represent the thematic approach to integrating subject matter. Typically, this thematic approach curriculum development begin with a theme".

In conjunction with the integrated thematic learning, in Curriculum 2013 (the game No. 67, 2013), Lesson Indonesian become a motor for driving and for other subjects. It appears once in charge of Core Competence (KI) and the Basic Competency (KD) in Subjects Indonesian in early elementary classes (classes I-III) in which loaded with science and social studies subjects. In other words, the curriculum of 2013, science and social subjects are not presented in a separate subject with its own $\mathrm{KI}$ and $\mathrm{KD}$, but the charge $\mathrm{KI}$ and its $\mathrm{KD}\urcorner$ put in charge of Indonesian subjects. Therefore, it is necessary to develop teaching materials that accommodate each characteristic Indonesian subjects, social studies, and science are combined in the early grades will be used as teaching material subjects Indonesian Education in Early Elementary Classroom. Through this teaching material students are expected to gain theoretical example PGSD packaging materials that accommodate the characteristics of social studies and science combined with Indonesian subjects, who also did not ignore the characteristics of Indonesian subjects. Therefore, the teaching materials developed in this study is an urgent need to be realized in order to provide supplies for prospective elementary school teachers who will spearhead the implementation of Curriculum 2013 in SD. The provision embodied in the form of teaching materials Subjects Indonesian Education in Early Elementary Classroom, in which are given concrete examples of packaging planning, implementation, and assessment of learning Indonesian, combined with teaching science and social studies.

Teaching materials produced through this research in addition to accommodate the characteristics of Indonesian subjects, social studies, and science are combined based on a thematic approach, also based on a scientific approach (scientific approach). Learning is a scientific process. Therefore Curriculum 2013 mandates the essence of the scientific approach or a scientific approach to learning. The 
scientific approach is believed to be the golden bridge and the development of attitudes, skills, and knowledge of learners. (Permendikbud, 2013). Furthermore expressed in Permendikbud (2013) that the scientific method refers to the techniques of the investigation of phenomena or symptoms, acquire new knowledge, or correcting and integrating previous knowledge.

Based learning approach is scientifically proven to be more effective results compared with traditional learning. The research proves that the traditional learning, retention of information of teachers by 10 percent after fifteen minutes and the acquisition of contextual understanding by 25 percent. In the scientific approach based learning, retention of information from the teacher for more than 90 percent after two days and the acquisition of contextual understanding by 50-70 percent (Permendikbud, 2013). To obtain the necessary learning integrated learning steps using a scientific approach, which consists of five steps, namely observation, ask, gather information, association, and communication (Permendikbud No. 81A, 2013: 43).

Teaching materials is one important aspect that contains the knowledge, concepts, facts, tangible material, both printed and unprinted used as a source of learning materials. Development of teaching materials in this study sought meets the requirements outlined by the National Education Standards Agency (BSNP) which includes: feasibility contents which include compliance with the standards and basic competencies, the accuracy of the material, the material supporting the learning, the feasibility of the presentation which include presentation techniques, presentation of learning, the completeness of the presentation; and the feasibility of covering linguistic conformity with the level of development of learners, communicative, keruntutan and unity of ideas.

This research is the emphasis on optimizing competence PGSD students as prospective elementary school teachers in the curriculum implies 2013 through the development of teaching materials MK Indonesian Education in Early Elementary Classroom by integrating field-Social Science-Based Scientific Approach. Judging from the research-based scientific substance, the substance of this study is a new topic by researchers and other researchers because the scientific basis is an implementation of Curriculum 2013. However, from the development of teaching materials already done previous studies, which were conducted Rukmi and Sukartiningsih (2002 ); Damayanti and Sukartiningsih (2004); Sukartiningsih (2005); Sukartiningsih and Yermiandhoko (2008); Sugiarto (2009); and Ibrahim and Sukartiningsih (2012). These studies represent research and development of instructional media and thematic learning Indonesian. This research is continuing substance and topics such studies with the aim to generate continuous improvement in accordance with the development of science and practical needs in the field.

Based on the description in the background, this study will answer the following general problem formulation How Instructional Materials Development Course Indonesian Education in Early Grades SD-IPS Integrated Science-Based
Approach to Optimizing Scientific Competence PGSD Student Department. Furthermore, the formulation of such a common problem, detailed formulation of specific issues. In the first study focused on the formulation of a special issue number 1, namely MK How is the preparation of Instructional Materials Indonesian Education in Early Grades SD-IPS Integrated Science-Based Approach to Optimizing Scientific Competence Students of PGSD?

The specific objectives of the first study is to describe the feasibility of teaching materials Subjects Indonesian Education in Early Elementary Classroom integrated science-based IPS Scientific approach to optimize student competence PGSD Department. In general the results of this development is expected to contribute to the improvement of the competence and quality of graduates PGSD, especially the ability to design, implement, and assess learning Indonesian in Early Elementary Classroom integrated IPAbased IPS Scientific approach.

\section{RESEARCH METHODS}

This research is research Research \& Development ( $R$ \& D) Borg and Gall (1983), which consists of 10 stages, namely (1) survey: analysis of the needs and constraints, (2) the Review of literature and products related research, (3) the development of the draft (4) test expert, (5) a revision the main products, (6) a limited field test, (7) the revision of the products have been applied, (8) major field test, (9) the revision of the final product (10) dissemination to a wider arena. Phase-10 is not performed in this study because this phase is done through the relevant institutions. The procedure of this study was designed as follows.

In the first year, the focus of activities include the analysis of the needs and constraints analysis. The objectives of the phase 1 is the assessment and identification of problems and the fact that the case of Indonesian Education Course in Early Elementary Classroom integrated IPA-IPS. Activities include (1) Survey and the observation and analysis of the needs analysis related constraints Subjects Indonesian Education in Early Grades integrated SD-IPS in PGSD IPA; (2) Interview with the faculty in PGSD from several regions in Indonesia. Interviews with students related to the activities carried out in the lecture and efforts to optimize PGSD student competence in designing courses Indonesian Education in Early Elementary Classroom integrated IPA-IPS. Analysis of constraints reflected on the problems faced by lecturers to improve their professional ability, especially in the development of student competence draft the Indonesian Education Courses in Early Grades integrated SD-Social Science-Based Scientific Approach; (3) the Review theoretical concepts associated with learning Indonesian, science, and social studies courses Indonesian Education in Early Grades integrated SD-Social Science, Scientific approach; (4) drafting teaching material Course Indonesian Education in Early Grades integrated SD-Social Science-Based Scientific Approach (Class I-III SD), and (5) Validation Expert. Survey data collection needs and constraints analysis conducted by questionnaire and 
interview guide. Data analysis techniques used to process the data analysis of the needs and constraints in the form of questionnaires (quantitative data) were analyzed by simple statistics such as percentage and mean.

The variables and operational definitions of each variable is explained as follows.

1. The development process is a series of product formulation, testing the device so as to produce products such as teaching materials Subjects Indonesian Education in Early Elementary Classroom integrated science-based IPS Scientific approach to dissemination.

2. The teaching materials is one important aspect that contains the knowledge, concepts, facts, tangible material, both printed and unprinted used as a source of learning materials.

3. Model thematic integrative learning is packaging in the form of themes that integrate multiple subjects.

4. The Scientific Approach (scientific approach) is a learning approach, characterized by scientific (scientific), which consists of five steps, namely observation, ask, gather information, association, and communication.

5. Students PGSD Competence is the ability of elementary school student teachers in planning, implementing, and assessing thematic integrative learning in elementary school.

\section{ANALYSIS}

Results of research in compiling teaching materials products MK Indonesian Education in Early Elementary Classroom integrated science-based IPS Scientific approach can be described as follows.

A. Preparation of draft teaching materials Subjects Indonesian Education in Early Grades integrated SDSocial Science-Based Scientific Approach

In the first year of this study have been compiled draft instructional materials Subjects Indonesian Education in Early Elementary Classroom integrated science-based IPS Scientific approach with the following characteristics.

1. Material teaching materials Subjects Indonesian Education in Early Grades integrated SD-IPS IPA prepared in accordance with the characteristics of Indonesian Course, science, and social studies and arranged thematically integrated

2. Material teaching materials relevant to the subject matter Indonesian, science, and social studies curriculum is based on the charge in 2013.

3. Systematic teaching material consists of a cover page, Preface, table of contents, use of guide books, materials, glossary, index and bibliography.

B. Validation Draft Subjects Subjects Indonesian Education in Early Grades integrated SD-Social Science-Based Scientific Approach.

Validation is done to check the suitability of the material (material validation), presenting and teaching materials kegrafikaan order to obtain valid and feasible to implement. Validation is done by experts who are experts in the field of education to-SD's language appears logical, science, and social studies. Based on the validation conducted on the draft teaching material Course Indonesian Education in Early Elementary Classroom integrated science-based IPS Scientific approach can be described as follows:

1. Validation of Subjects of Matter Eligibility

Validation of teaching materials on the feasibility of the material is done by experts who are experts in the field of education to-SD's language appears logical, science, and social studies. The validation results can be described as indicated in Table 1 as follows

Table 1. Results of Validation Draft Feasibility material Subjects

\begin{tabular}{|c|c|c|}
\hline $\begin{array}{l}\mathbf{N} \\
\mathbf{o}\end{array}$ & Item & Score \\
\hline A. & \multicolumn{2}{|l|}{ Material Relevance } \\
\hline 1 & $\begin{array}{l}\text { Completeness material contains } \\
\text { learning outcomes (learning } \\
\text { outcomes) that supports the } \\
\text { achievement of student competence }\end{array}$ & 4 \\
\hline 2 & $\begin{array}{l}\text { Breadth of material, related to the } \\
\text { topics integrated into Indonesian, } \\
\text { science, and social studies }\end{array}$ & 4 \\
\hline 3 & $\begin{array}{l}\text { The depth of the material, which } \\
\text { includes the deepening of the theory } \\
\text { of learning Indonesian in early } \\
\text { elementary school class integrated } \\
\text { IPS and IPA }\end{array}$ & 4 \\
\hline B. & \multicolumn{2}{|l|}{ Material accuracy } \\
\hline 1 & $\begin{array}{l}\text { Materials (examples and exercises) } \\
\text { are presented based on facts, } \\
\text { concepts, principles and theories } \\
\text { Indonesian, science, and social } \\
\text { studies so as to avoid misconceptions } \\
\text { in students. }\end{array}$ & 3 \\
\hline 2 & $\begin{array}{l}\text { Illustration given in accordance with } \\
\text { the rules and learning the Indonesian } \\
\text { language, science, and social studies } \\
\text { in an integrated SD and accurate }\end{array}$ & 3 \\
\hline C. & \multicolumn{2}{|l|}{ Support Material } \\
\hline 1 & $\begin{array}{l}\text { Support materials (examples, } \\
\text { exercises, problems, and } \\
\text { bibliography) in accordance with the } \\
\text { development of science and } \\
\text { technology }\end{array}$ & 4 \\
\hline 2 & $\begin{array}{l}\text { Recency features (definition, } \\
\text { description and example) reflect } \\
\text { current events using the referral last } \\
\text { five years }\end{array}$ & 4 \\
\hline 3 & $\begin{array}{l}\text { Contextual, presented from the } \\
\text { immediate environment with the daily } \\
\text { life of students }\end{array}$ & 4 \\
\hline 4 & $\begin{array}{l}\text { Completeness of the materials } \\
\text { developed according to the }\end{array}$ & 4 \\
\hline
\end{tabular}




\begin{tabular}{|c|l|c|}
\hline $\begin{array}{c}\mathbf{N} \\
\mathbf{o}\end{array}$ & \multicolumn{1}{|c|}{ Item } & Score \\
\hline & $\begin{array}{l}\text { characteristics Indonesian, science, } \\
\text { and social studies, scientific approach }\end{array}$ & \\
\hline 5 & $\begin{array}{l}\text { Encouraging students to be able to } \\
\text { understand, identify, troubleshoot, } \\
\text { and apply the learning materials using } \\
\text { a scientific approach }\end{array}$ & 4 \\
\hline \multicolumn{2}{|c|}{ Jumlah } & 38 \\
\hline \multicolumn{2}{|c|}{ Percentage } & $\begin{array}{c}\text { Sangat } \\
\text { Layak }\end{array}$ \\
\hline
\end{tabular}

Note: The value range $0-4$

From Table 1 it appears that the results validate the feasibility of teaching materials have which can be explained as follows:

a. Suitability material aspects include:

1) Completeness of the material contains learning outcomes (learning outcomes) that supports the achievement of the competence of the students obtain a score of 4 ;

2) breadth of material, related to the topics integrated into Indonesian, science, and social studies to get a score of 4 ;

3 ) the depth of the material concerning the deepening of the theory that includes learning material Indonesian in early elementary grade integrated science and social studies, getting a score of 4 ..

b. Aspects of the accuracy of the material, with the following criteria:

1) Content (examples and exercises) are presented based on facts, concepts, principles and theories Indonesian, science, and social studies so as to avoid misconceptions in students getting a score of 3 .

2) illustration accordance with the rules and learning Indonesian, rules and learning science, and social studies learning principles and presented in an integrated SD and accurately obtain a score of 3 .

c. Learning support material aspects, with the following criteria:

1) support materials (examples, exercises, problems, and bibliography) in accordance with the development of science and technology to get a score of 4 .

2) Recency features (definition, description and example) reflect current events using the referral last five years to get a score of 4

3) Contextual, served from the immediate environment with the daily life of the students receive a score of 4 .

4) Completeness of the material developed in accordance with the characteristics of
Indonesian, science, and social studies and scientific approach to obtain a score of 3

5) Encourage students to be able to understand, identify, troubleshoot, and apply the learning materials using a scientific approach to obtain a score of 4 .

Overall, the results validate the feasibility of obtaining the material with a percentage score of 38 feasibility of teaching materials is $95 \%$. The results showed that the teaching materials developed in this study is very feasible and can be used with slight revisions.

2. Validation of the Feasibility teaching materials Presentation

Validation of teaching materials was also based on the presentation format. The results validate the feasibility of the presentation can be described as follows.

Table 2. Results of Validation Draft Feasibility material I Subjects

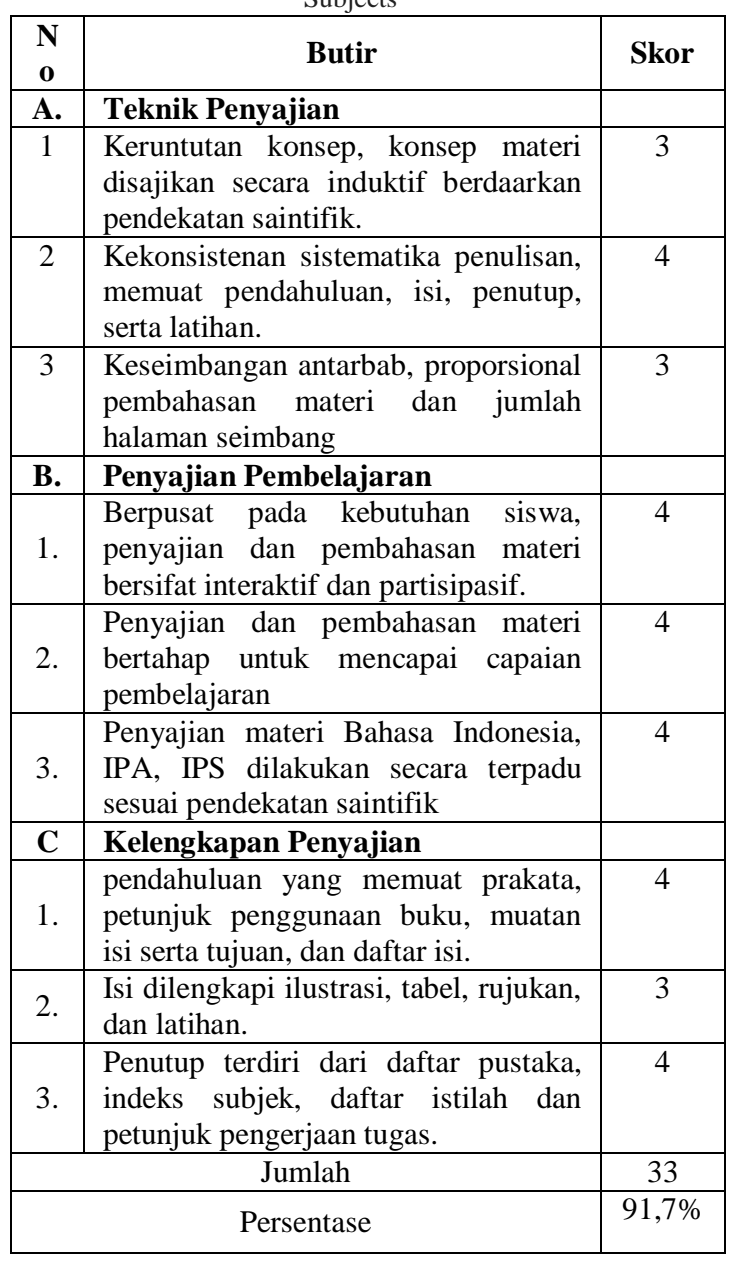




\begin{tabular}{|c|c|c|}
\hline $\begin{array}{c}\mathbf{N} \\
\mathbf{0}\end{array}$ & Butir & Skor \\
\hline & Kriteria & $\begin{array}{c}\text { Sangat } \\
\text { Layak }\end{array}$ \\
\hline
\end{tabular}

From Table 2 it appears that the validation presentation of teaching material consists of three aspects, namely presentation techniques, presentation of learning, and completeness of the presentation. Results of the validation of each of these aspects can be explained as follows.

a. Aspect Presentation Techniques include:

Results of the validation aspects of presentation techniques include:

1) keruntutan concept, the concept of the material presented inductively based scientific approaches to get a score of 3 ;

2) systematic consistency of each chapter contains an introduction, contents and cover, as well as exercises to get a score of 4 ;

3) Balance antarbab, proportionate and number of pages of the material balance (weight and almost the same amount) received a score of 3 .

b. Presentation aspects of learning, including:

Results of the validation aspects of presentation techniques include:

1) Focusing on the needs of students, the presentation and discussion of the material is interactive and participatory. getting a score of 4;

2) presentation and discussion of the material Presentation and discussion of the material gradually to achieve the learning outcomes receive a score of 4 ;

3) Presentation of Indonesian material, Science, Social Studies carried out in an integrated manner with the steps appropriate scientific approach to get a score of 4.

c. Presentation Completeness aspects, including:

1) an introduction that includes the preface, instructions for use books, the content and purpose of the charge, and a list of isi.mendapatkan score of 4 ;

2) Fill furnished with pictures, illustrations, tables, references, and ending the practice. getting a score of 3 ;

3) The cover consists of a bibliography, a subject index, glossary and instructions for performing tasks get a score of 4

Validation feasibility aspects of the presentation of the results obtained with the 33 percentage of $91.7 \%$. These results indicate that the teaching materials developed in this study is feasible and can be implemented with little revision.
3. Validation of the Feasibility Linguistic teaching materials

Validation of teaching materials on the feasibility aspect of language carried out by Indonesian experts. Results validate the feasibility of teaching materials on the feasibility aspect of language described as follows.

Table 3. Results of the Feasibility Linguistic Validation Draft I Subjects

\begin{tabular}{|c|c|c|}
\hline $\begin{array}{l}\mathbf{N} \\
\mathbf{0}\end{array}$ & Butir & Skor \\
\hline A. & \multicolumn{2}{|c|}{$\begin{array}{l}\text { Kesesuaian dengan Tingkat Perkembangan } \\
\text { Siswa }\end{array}$} \\
\hline 1. & $\begin{array}{l}\text { Materi yang ada pada bahan ajar } \\
\text { disajikan dengan bahasa yang mudah } \\
\text { dipahami dan menuntut kemampuan } \\
\text { berpikir kritis dengan menghindari } \\
\text { kalimat yang bermakna bias dan } \\
\text { sarkasme. }\end{array}$ & 3 \\
\hline 2. & $\begin{array}{l}\text { Bahasa yang digunakan sesuai dengan } \\
\text { tingkat kemampuan mahasiswa. }\end{array}$ & 4 \\
\hline B. & \multicolumn{2}{|l|}{ Komunikatif } \\
\hline 1. & $\begin{array}{l}\text { Keterpahaman pesan, materi disajikan } \\
\text { secara komunikatif dengan bahasa } \\
\text { yang mudah dipahami mahasiswa. }\end{array}$ & 4 \\
\hline 2. & $\begin{array}{l}\text { Ketepatan tata bahasa dan ejaan pada } \\
\text { pemilihan kata dan kalimat } \\
\text { berpedoman pada kaidah tata bahasa } \\
\text { Indonesia dan EYD }\end{array}$ & 4 \\
\hline 3. & $\begin{array}{l}\text { Kebakuan istilah dan simbol } \\
\text { digambarkan melalui ilustrasi yang } \\
\text { tepat, bermakna, dan konsisten }\end{array}$ & 4 \\
\hline C. & \multicolumn{2}{|c|}{ Keruntutan dan Keterpaduan Alur Pikir } \\
\hline 1. & $\begin{array}{l}\text { Keruntutan bahasa yang digunakan } \\
\text { dalam setiap paragraf dan wacana } \\
\text { yang terdapat pada bahan ajar bersifat } \\
\text { deduktif, induktif, naratif, maupun } \\
\text { deskriptif }\end{array}$ & 4 \\
\hline 2. & $\begin{array}{l}\text { Keruntutan dan keterpaduan materi, } \\
\text { penyampaian pesan antarparagraf } \\
\text { memiliki hubungan logis }\end{array}$ & 4 \\
\hline & Jumlah & 27 \\
\hline & Persentase & $96,4 \%$ \\
\hline & Kriteria & $\begin{array}{l}\text { Sangat } \\
\text { layak }\end{array}$ \\
\hline
\end{tabular}

Table 3. The visible results of the validation aspects of language teaching materials consists of three aspects, namely conformity with the level of student development, communicative, and keruntutan and integration flow of thought, each of which is described as follows.

a. Aspects of conformity with the developmental level of students, include:

1) The material on teaching materials are presented in an easily understood and require critical thinking skills by avoiding meaningful sentence sarkasme. mendapatkan bias and a score of 3; 
2) The language used in accordance with the level of students' ability to get a score of 4 .

b. Communicative aspects, including:

1) Keterpahaman messages, materials presented in communicative language that is easy to understand the student gets a score of 4 ;

2) The accuracy of grammar and spelling in the selection of words and sentences based on the rules of grammar Indonesia and EYD get a score of 4;

3) Kebakuan terms and symbols depicted through illustrations proper, meaningful, and consistently get a score of 4 .

c. Keruntutan aspect and integration mindset, include:

1) keruntutan language used in each paragraph and discourse contained in teaching materials deductive, inductive, narrative, descriptive and get a score of 4 ;

2) keruntutan and coherence of matter, delivering a message antarparagraf have a logical relationship to get a score of 4 .

Overall, the results validate the feasibility aspect of language to obtain a score of 27 by percentage of aspects of the feasibility of presentation is $96.4 \%$. The results show that the language in the draft teaching materials is very feasible and can be used with slight revisions.

4. Validation teaching materials from the aspect of feasibility Kegrafikaan

Results of the validation aspect kegrafikaan developed teaching materials that can be described as follows.

Table 4. Results Validation Draft Feasibility Kegrafikaan I Subjects

\begin{tabular}{|c|l|c|}
\hline $\begin{array}{c}|c| \\
\text { N } \\
\text { o }\end{array}$ & \multicolumn{1}{|c|}{ Butir } & Skor \\
\hline A. & Ukuran Buku & 4 \\
\hline 1 & $\begin{array}{l}\text { Ukuran bahan ajar sesuai dengan } \\
\text { standar ISO A4 }\end{array}$ & 4 \\
\hline 2 & $\begin{array}{l}\text { materi dan ukuran bahan ajar yang } \\
\text { disajikan sesuai dengan nilai estetika } \\
\text { tata letak dan jumlah halaman }\end{array}$ & \\
\hline B. & $\begin{array}{l}\text { Desain Kulit Buku } \\
\text { Tata letak dalam desain bahan ajar } \\
\text { diatur secara proporsional dan } \\
\text { menarik }\end{array}$ & 3 \\
\hline 2. & $\begin{array}{l}\text { Tipografi kulit sampul sesuai dengan } \\
\text { pembelajaran terpadu berkarakter } \\
\text { Bahasa Indonesia, IPA, dan IPS dan } \\
\text { menggunakan huruf yang mudah } \\
\text { dibaca serta ukuran huruf yang } \\
\text { proporsional untuk dibaca oleh }\end{array}$ & \\
\hline
\end{tabular}

\begin{tabular}{|c|c|c|}
\hline $\begin{array}{l}\mathbf{N} \\
\mathbf{0}\end{array}$ & \multirow[t]{2}{*}{ Butir } & \multirow[t]{2}{*}{ Skor } \\
\hline & & \\
\hline 3. & $\begin{array}{l}\text { Ilustrasi desain kulit } \text { buku } \\
\text { mencerminkan isi buku, bentuk, } \\
\text { warna, ukuran yang sesuai dan } \\
\text { propoesional. }\end{array}$ & 3 \\
\hline C. & \multicolumn{2}{|l|}{ Desain Isi Buku } \\
\hline 1. & $\begin{array}{l}\text { Penempatan unsur tata letak dalam } \\
\text { bahan ajar konsisten berdasarkan } \\
\text { pola. }\end{array}$ & 4 \\
\hline 2. & $\begin{array}{l}\text { Kesesuaian judul, subjudul, dan } \\
\text { nomor halaman. }\end{array}$ & 4 \\
\hline 3. & $\begin{array}{l}\text { Menggambarkan isi/materi } \text { dan } \\
\text { mengungkapkan karakter objek. }\end{array}$ & 4 \\
\hline 4. & $\begin{array}{l}\text { Tipografi isi dalam bahan ajar } \\
\text { sederhana dan mudah dipahami. }\end{array}$ & 4 \\
\hline 5. & $\begin{array}{l}\text { Ilustrasi isi dalam bahan ajar } \\
\text { memperjelas dan mempermudah } \\
\text { pemahaman materi bahan ajar. }\end{array}$ & 4 \\
\hline & Jumlah & 38 \\
\hline & Persentase & $95 \%$ \\
\hline & Kriteria & $\begin{array}{l}\text { Samga } \\
\mathrm{t} \\
\text { Layak }\end{array}$ \\
\hline
\end{tabular}

From Table 4 it appears that the validation kegrafikaan includes three aspects, namely the size of the book, the design of book covers, book design. Each of these aspects of DAPT is described as follows.

a. Aspects of Book Size, covers

1) in accordance with the ISO standard A4 size used to get a score of 4;

2) the material and size of the teaching materials were prepared in accordance with the aesthetic value of the layout and the number of pages to get a score of 4 .

b. The design aspect of the foreskin, covering

1) The layout in the design of teaching materials and interesting set proportionally get a score of 3 ;

2) Typography cover skin according to the character of Indonesian integrated learning, science, and social studies and use the letters readable font size proportional to be read by students. getting a score of 4 ;

3) Illustration design of book covers reflect the contents of the book, shape, color, size appropriate and balanced propoesional mendapatkan 3.

c. Design aspects of the contents, covers

1) The placement of elements of the layout in a consistent teaching materials based pola mendapatkan score of 4 ; 
2) Suitability title, subtitle, and page number. getting a score of 4 ;

3) Describe the contents and reveal the character of objek.mendapatkan score of 4;

4) Typography contents of teaching materials simple and understandable to get a score of 4 ;

5) Illustration of the content of the teaching materials to clarify and simplify the understanding of teaching materials. getting a score of 4 .

Validation of the results obtained score kegrafikaan feasibility aspect is 38 with a percentage of $95 \%$. These results can be interpreted that the teaching materials developed in this study is feasible and can be used with little revision.

Tabel 5. Rekapitulasi Hasil Validasi Draf I Bahan Ajar

\begin{tabular}{|c|c|c|c|c|}
\hline \multirow[b]{2}{*}{ No } & \multirow[b]{2}{*}{$\begin{array}{l}\text { Kriteria } \\
\text { Bahan ajar }\end{array}$} & \multicolumn{3}{|c|}{ Penilaian Validator } \\
\hline & & $\begin{array}{c}\text { Jumlah } \\
\text { Skor } \\
\text { Peroleha } \\
\text { n }\end{array}$ & $\begin{array}{c}\text { Persentase } \\
(\%)\end{array}$ & Kategori \\
\hline 1 & $\begin{array}{l}\text { Kelayakan } \\
\text { Materi }\end{array}$ & 38 & $95 \%$ & $\begin{array}{r}\text { Sangat } \\
\text { layak }\end{array}$ \\
\hline 2 & $\begin{array}{r}\text { Kelayakan } \\
\text { Penyajian }\end{array}$ & 33 & $91,7 \%$ & $\begin{array}{r}\text { Sangat } \\
\text { layak }\end{array}$ \\
\hline 3 & $\begin{array}{c}\text { Kelayakan } \\
\text { Bahasa }\end{array}$ & 27 & $96,4 \%$ & $\begin{array}{r}\text { Sangat } \\
\text { layak }\end{array}$ \\
\hline 4 & $\begin{array}{l}\text { Kelayakan } \\
\text { Kegrafikaan }\end{array}$ & 38 & $95 \%$ & $\begin{array}{r}\text { Sangat } \\
\text { layak }\end{array}$ \\
\hline & Rata-Rata & \multicolumn{2}{|c|}{$94,5 \%$} & $\begin{array}{r}\text { Sangat } \\
\text { layak }\end{array}$ \\
\hline
\end{tabular}

Data in Table 5. Indicates that 1) the feasibility aspects of language gets a percentage of $95 \%$ can be interpreted very feasible to use with little revision; 2) aspects of the feasibility of presenting a percentage of $91.7 \%$ can be interpreted very feasible to use the revision; 3) the feasibility aspect of the material with a percentage of $96.4 \%$ can be interpreted very feasible to use the revision; 4) kegrafikaan feasibility aspects with a percentage of $95 \%$ can be interpreted very fit for use with minimal revision. Thus the final percentage of votes against the draft I validator is $73.85 \%$ of teaching materials can be interpreted very fit for use with minimal revision.

\section{RECOMMENDATIONS}

From the results of this research can be submitted the following recommendations:

1. Teaching materials MK Indonesian Education in Early Grades SD Integrated Science-Based IPS Scientific Approach compiled through research is expected to provide one solution providing teaching materials eligible to be implemented for students PGSD

2. It should be arranged in college teaching materials relevant to the demands of the curriculum and the needs of society, the curriculum in 2013 with thematic integrative approach in SD.

3. The results showed that the teaching materials prepared by the experts validation activities may increase the feasibility of teaching materials before implemented

\section{REFERENCE}

[1] Borg, Walter R. and Gall, Meredith Damien. 1983. Applying Educational Research: A Practical Guide for Teachers. New York: Longman.

[2] Damayanti, Maryam Isnaini and Wahyu Sukartiningsih. 2004 Pembelajaran Konstruktivisme dalam Meningkatkan Kemampuan Membaca dan Menulis Permulaan Di Kelas 1 SDN Arjosari I. Laporan Penelitian Tidak Diterbitkan. Surabaya: Lembaga Penelitian UNESA.

[3] Dikti. 2006. Standar Kompetensi Guru Kelas. Jakarta: Dikti

[4] Fogarty, Robin. 1991. The mindful school: How to integrate the curricula. Illinois: Skylight Publishing.

[5] Ibrahim, Muslimin. 2012. Menumbuhkan Kemampuan Berpikir dan Karakter Potisif Siswa SD melalui Pengembangan dan Diseminasi Model Pembelajaran Pemaknaan. Laporan Penelitian. Tidak diterbitkan, Surabaya: LPPM Unesa.

[6] Kemdikbud, Badan Pengembangan Sumber Daya Manusia Pendidikan dan Kebudayaan dan Penjaminan Mutu Pendidikan. 2013. Konsep Pendekatan Saintifik.

[7] Peraturan Pemerintah Nomor 19 Tahun 2005 tentang Standar Pendidikan Nasional

[8] Permendikbud Nomor 542013 tentang Standar Kompetensi Lulusan

[9] Permendikbud Nomor 672013 tentang Kerangka Dasar dan Struktur Kurikulum SD-MI

[10] Permendikbud RI Nomor 81A Tahun 2013 tentang Implementasi Kurikulum

[11] Rukmi, Asri Susetyo dan Wahyu Sukartiningsih. 2002. Pengembangan Media Kartu Kata Bergambar untuk Pembelajaran Membaca dan Menulis Permulaan di Kelas 1 SD. Laporan Penelitian Tidak Diterbitkan. Surabaya: Lembaga Penelitian UNESA.

[12] Sugiarto, Bambang, dkk. 2009. Pengembangan Bahan Ajar Tematik Kelas I SD untuk Pemberdayaan Kemampuan Berpikir, Kecakapan Hidp, Psikomotor, dan Hasil Belajar Kognitif Siswa. Laporan Penelitian. Tidak Diterbitkan. Surabaya: Lemlit UNESA.

[13] Sukartiningsih, Wahyu dan Yermiandhoko, Yoyok. 2008. Pengembangan Media CD Interaktif untuk Pembelajaran Membaca Permulaan di kelas 1 Sekolah Dasar. Laporan Penelitian. Tidak Diterbitkan. Surabaya: Lemlit UNESA.

[14] Sukartiningsih, Wahyu, dkk. 2005. Penggunaan Strategi Problem Based Learning untuk Meningkatkan Kemampuan Membaca Kritis Mahasiswa Program D2 PGSD-UNESA. Laporan Penelitian. Tidak Diterbitkan. Surabaya: Lemlit UNESA.

[15] Undang-Undang Nomor 14 Tahun 2005 tentang Guru dan Dosen. 